\title{
Analysis on the Governance Structure with the Core of Professional Construction in Higher Vocational Colleges
}

\author{
Jing Wang \\ Dalian Vocational Technical College \\ Heilongjiang Province, China
}

\begin{abstract}
It is of great significance to the promotion of higher vocational education on economic and social development that analyzing the governance structure of Chinese higher vocational colleges with the core of professional construction and reference of advanced international TAFE. This paper, starting from the introduction of TAFE, structured the organization dimension oriented with professional construction and envisaged the reconstruction of Chinese higher vocational college governance structure.
\end{abstract}

Keywords-vocational education; model; professional construction; college structure

\section{INTRODUCTION}

Vocational education, especially higher vocational education, has been increasingly emphasized by all the countries with the economic development and social progress. Vocational education reform and development have been the important methods to push the adjustment of economic structure and the growth model of innovative economy in China, which regards the national model college construction as the carrier to promote the training model reform of higher vocational professionals with Chinese characteristics.

Australian higher vocational education is a global leader and its scientific training model of professionals is highly praised by all countries. TAFE Institute, the common pattern of higher vocational education in Australia, is invested and managed by the government and its diplomas are issued by the government, which is similar to the public higher vocational colleges, the principal part in Chinese higher vocational education. We can learn a lot from its governance structure and professionals training experience.

\section{AUSTRALIAN HIGHER VOCATIONAL PROFESSIONALS TRAINING MODEL- CERTIFICATE FRAMEWORK}

The evaluation and certificate of skilled talents in Australia totally depend on the national standards-certificate framework. TAFE Institute regards students' certificate as its distinct talent training target. And it is hierarchical in different fields: the first and second level means the basic skills; the third level means some practical operation ability; and the fourth level means the ability to independently accomplish some work.
TAFE Institute, oriented with every certificate, designs the training package and regulates the quality standards with the cooperation of industries and enterprises. The training package includes the compulsory and optional parts. The former includes knowledge, skill and evaluation guidance, while the latter is the means of teachers to guarantee teaching quality. And the quality standard includes students' satisfactory degree, evaluation of employers and database of students' academic accomplishment.

Australian higher vocational professionals construction and reform start from the college governance structure and its main advantages after the reform include:

\section{A. Sector setting breaks the restriction of "department", which shows the core of certificate system}

Oriented with "certificate system construction", each teaching sector respectively carries out the development, construction and registration of different types of courses according to the requirement of "optimization of professional talent training process”.

And in terms of different certificates, all kinds of courses include public basic courses, professional basic courses, professional theory courses, professional skills courses and professional minor courses. Every certificate selects the registered courses according to its own construction needs so as to make various courses form an "education supermarket". There is only the deputy director in each teaching sector, and all the deputy directors are led by the director of research study sector to jointly make the course management and operation. Other business segment provides the support and guarantee around the certificate construction. Such operation model has realized the flat governance, straightened the construction process of certificate system and promoted the cultivation of higher vocational talents with the core of "certificate".

\section{B. The separation of decision, execution and supervision to} make the decision more scientific, the execution stronger and the supervisor more powerful.

The management operation of TAFE Institute is clearly divided in three parts: decision system, systematic executive system without direct relation with decision, as well as the supervision and evaluation system facing all the works. Member institution of management committee can ensure the 
decision to adapt to institute development construction demands, meet with the government education policy, as well as satisfy the demands of society and enterprise with talents training. Management committee, a independent decision institution, has a rather small number of members, so it is easy to form the design and ensure the timeliness of decision. The CEO regularly holds daily executive meetings to make the executive level quickly and accurately grasp the connotation of the decision and ensure its exact implementation. A systematic and strong executive system formed around the construction of certificate is conducive to the effective implementation of the decision. And clear and independent supervision and evaluation institution can ensure the effect of its implementation.

\section{More convenient, scientific and effective working procedures}

The decision of Management Committee is not affected by the executive level, nor directly intervened by the parent bodies, but independently made according to the demands of market, society and enterprises. Such method can reduce the opportunity cost of design and make fast reaction to the emergence and major issues. Its all executive parts care not influenced by other sectors and crossed with other businesses. CEO can directly connect with the member on the specific affairs, which will exempt the burdensome procedures of applying for the permission of Management Committee and greatly improve the executive efficiency. All the sectors and members in the executive level cannot establish direct relation with the supervisory level, so they are unable to hinder the implementation of supervision, and then the supervision on all parts of certificate construction will be more directive, fair and transparent.

\section{Realizing the in-depth integration of government, enterprises and higher vocational colleges}

The participation of government and enterprises in the college management is showed in the three aspects. Firstly, they directly take part in the decision-making, which is different from the guidance of the government to the specific affairs in colleges, and the simple college-enterprise cooperation purely about internship and employment. It relies on the influence on the college running direction and macro development strategy to make the talents training more corresponding to the requirements of government education and talents demand of enterprises. Secondly, they directly participate in the evaluation with talents training quality (certificate quality). The college capacity and level is not promoted by itself nor defined by the general "social reputation", but measured by the quantities standards set by all interested parties. Thirdly, enterprises directly participate in the teaching process by selecting professional skilled talents to teach in colleges and providing productive places for practical teaching. College practical training rooms are integrated with enterprise production base to introduce the real workplace into the campus. The three-dimension guidance, supervision effect and integration process makes college function positioning more accurate
Through the above analysis, we believe that the governance structure reconstruction of TAFE Institute is actually based on the theory of business process reengineering.

\section{CONSTRUCTION OF ORGANIZATION DIMENSION CONCENTRATED ON PROFESSIONAL CONSTRUCTION PROCESS}

The main business processes of higher vocational colleges, with the core of professional construction, covers the plan and standard formulation, course construction, practical teaching condition and evaluation system establishment. It can refer to the business process reengineering of enterprises to form its organization dimension concentrated on the professional construction. As the figure 1:

The organization dimension model can be divided into three parts:

\section{A. Professional construction}

Professional construction activities can be divided into direct and supportive activities according to the theory of value chain, which are completed by independent departments parallel to decision-making level under the existing management model. And the overall college structure is vertical. The goal of the professional construction process reengineering is to realize the transition from "vertical" to "flat". Such model can ensure the complete functions of the overall professional construction work, avoid the resource waste caused by the delivery, auditing and waiting for information under the original mode, and improve the work efficiency. Students become the main service object of each link, and the professional construction will be more systematic and scientific.

\section{B. Support monitoring platform}

The platform uniformly provides financial support, human resources and network system, and promotes the decisionmaking level to put more energy into the strategic planning of colleges and universities to ensure the successful professional construction. Especially, the network system, a huge operation system built and formed by lots of professionals, cannot run smoothly without the support of digital platforms.

\section{Decision-making level}

It needs assume the responsibility from the following three aspects: firstly, working out the strategic plan of college development; secondly, setting up and adjusting the dimension structure of professional construction process and function service to achieve the optimal efficiency; thirdly, make knowledge guidance and coordination with professional construction process and function service.

\section{CONSTRUCT THE GOVERNANCE STRUCTURE WITH THE CORE OF PROFESSIONAL CONSTRUCTION OF HIGHER VOCATIONAL COLLEGES IN CHINA}

"Governance" varies from "management": from the perspective of subjects, management is single while governance is diversified; from the perspective of objects, management is a closed system while governance is an open 
system; from the perspective of mechanism, management is pure submissiveness while governance is multiple checks and balances. Governance structure was originally a legal term, referring to the legal right relationship among the setting, operation and authorities. Corporate governance structure researches the internal incentive mechanism and checks and balances of power.

The main function of higher vocational colleges is to "educate students", which should be realized through the professional construction. The extension of corporate governance structure to the higher vocational college can define its governance structure as: the target is to train practical professionals meeting with the demands of economic and social development, and the organization structure, with the core of professional construction process, includes the decision-making, execution and supervision, which are balanced, supported and connected with each other. The governance structure of higher vocational colleges should form the mechanism of "multiple interactions", "effective checks and balances" and "diversified evaluation".

We reconstruct the governance structure of higher vocational colleges according to the reconstructed professional construction business process. The reconstructed one breaks the original division of functional departments, which is conducive to the cooperated accomplishment of professional construction process of all work teams.

The deputy dean of market operation department leads all the market teams to conduct market research and development. After confirming the client's intension, the market team and the professional teaching team of the teaching operation department will jointly establish a professional construction team that is in the charge of a professional construction director. The professional construction team should recruit enterprise personnel, actively investigate the requirements of enterprises on professional abilities, complete the certification of personnel training program and professional standards based on the requirements of enterprises, and formulate the professional personnel training scheme and professional standards on the basis of the research results to form a professional construction program.

The professional construction program, after the confirmation, needs to be approved by the professional management committee and transferred to the deputy dean of teaching operation department who will promote the professional teaching and the corresponding team after he confirmed the enrollment number of this major. Director of the major is main responsible for the professional teaching team and the deputy dean of teaching operation department, whose specific work is to the implementation of course construction, as well as the establishment of practical teaching condition and class teaching. At the beginning of professional construction, the director leads the whole team to provide skill guidance for the teaching process and constantly improve the professionals training program and standards to promote teaching team to independently and accurately implement the program and standard without the skill guidance. Quality supervisors should supervise and check the teaching work in the teaching process and correct those not meeting with the requirements. And in the whole process of professional construction, all teams should timely type the working conditions into the college information system to help related members accurately know the conditions in time.

The relation of majors and courses is showed in the figure 3 . Major $1,2,3 \ldots$ are set according to the market demands, and department A, B, C...respectively represents the management units covering different types of curriculums (equal to course supermarket). All majors select courses from various departments based on the construction program. Solid arrow represents the selection of professional core courses and dotted line represents the selection of minor courses and optional courses. The core courses of major 1 should be selected from department $\mathrm{A}$, and its minor courses and optional courses are respectively from department $\mathrm{B}$ and $\mathrm{C}$; while for major 2 and 3 , the selection is opposite. In other words, courses are not managed by the department as before but restructured by types: the major will not be restrained by the department but based on the construction process and it can select corresponding courses from different departments to form its own course system.

The parallel operation of all departments and related sectors will give full play to the advantage of flat governance model, namely, high-efficiency and convenience. It can make the principal part of college operation—professional construction more systematic, improve the communication with all parts and college entire environment and realized the whole scientific operation of colleges.

\section{CONCLUSION}

American higher vocational education adopts the framework system of academic degree and certificate (the corresponding skill standards), and the reengineering of its structure reengineering is based on the "certificate system construction process". Chinese higher vocational education is mainly the academic education, failing to make explicit requirements for the certificate, and its structure reengineering is oriented with "professional construction process".

The governance structure, resource allocation and management activities in Chinese higher vocational colleges should be oriented with "professional construction", which not only does not negate the effects of function, but better gives play to its auxiliary role.

\section{REFERENCES}

[1] Teng Jiadong. Modeling of business process reengineering in manufacturing enterprises[J]. Mechanical Design and Manufacturing, 2004(8). (In Chinese)

[2] Liu Jinhong. Discussion on the business process reengineering[M]. Wuhan University of Technology, 2002(3). (In Chinese)

[3] Jin Bingzhu. Repeated discussion on the problem of business process reengineering[M]. Zhengzhou University, 2006(5). (In Chinese)

[4] Ge Hongguang and Zhang Chengju. Theoretical research on business process reengineering[J]. Technology and Management, 2008(4) (In Chinese)

[5] $\mathrm{Xu}$ Jinshou. Features and inspirations of Australian professional education[J]. Vocational and Technical Education,2009. (In Chinese)

[6] Jiang Xingdai. Education supermarket - an ideal education construction and pursuit[J]. Journal of Tianjin Normal University,2008. (In Chinese) 